\title{
Attachment style and experiencing the symptoms of complicated grief after the death of a spouse - preliminary research among widowed women
}

Styl przywiązania a doświadczanie objawów żałoby powikłanej po śmierci współmałżonka badania wstępne wśród owdowiałych kobiet

\author{
Department of Psychology of Emotions and Personality, Maria Curie-Skłodowska University in Lublin, Lublin, Poland \\ Correspondence: Karolina Ludwikowska-Świeboda, Department of Psychology, Maria Curie-Skłodowska University in Lublin, pl. Litewski 5, 20-080 Lublin, Poland, e-mail: karolina.ludwikowska@gmail.com
}

Abstract Aim: The aim the study was to verify the relationship between global attachment style (the dimensions of avoidance and anxiety) and severity of complicated grief in widowed women. Materials and methods: A total of 60 women who experienced the loss of their spouse in the period of 1.2-9 years were included in the study $(M=4.52 ; S D=2.56)$. Inventory of Complicated Grief (ICG) was used to measure the severity of complicated grief. Experience in Close Relationships-Revised (ECR-R) was used to assess global attachment style. Results: Attachment anxiety and time elapsed from the death of a spouse are important predictors of complicated grief. The higher the level of attachment anxiety $(\beta=0.32 ; p<0.05)$ and the shorter the time elapsed from the loss $(\beta=-0.29 ; p<0.05)$, the higher the severity of complicated grief. Attachment avoidance is not a significant predictor of complicated grief. Conclusions: Individuals with high levels of attachment anxiety belong to a risk group for complicated grief; therefore, they need special support in coping with both the loss and new life circumstances.

Keywords: egrief, coping with loss, widowhood, attachment style

Streszczenie

Cel: Celem prezentowanych badań była weryfikacja zależności między globalnym wzorcem przywiązania (wymiarami unikania i niepokoju) a nasileniem żałoby powikłanej u owdowiałych kobiet. Materiał i metoda: W badaniach wzięło udział 60 kobiet, które doświadczyły straty współmałżonka w okresie $1,2-9$ lat $(M=4,52 ; S D=2,56)$. Do pomiaru żałoby powikłanej wykorzystano Inwentarz Żałoby Powikłanej (Inventory of Complicated Grief, ICG). Do badania globalnego stylu przywiązania wykorzystana została Zrewidowana Skala Doświadczeń w Bliskich Relacjach (Experience in Close Relationships, ECR-R). Wyniki: Istotnymi predyktorami żałoby powikłanej są niepokój w przywiązaniu i okres, jaki upłynął od śmierci współmałżonka. Im wyższy poziom niepokoju w przywiązaniu $(\beta=0,32 ; p<0,05)$ i im krótszy czas od utraty $(\beta=-0,29$; $p<0,05)$, tym większe nasilenie żałoby powikłanej. Unikanie $\mathrm{w}$ przywiązaniu nie jest istotnym predyktorem żałoby powikłanej. Wnioski: Osoby charakteryzujące się wysokim poziomem niepokoju w przywiązaniu należą do grupy ryzyka powikłań procesu żałoby, wymagają więc szczególnego wsparcia w radzeniu sobie z utratą i zmienionymi realiami życiowymi.

Słowa kluczowe: żałoba, radzenie sobie z utratą, wdowieństwo, styl przywiązania 


\section{INTRODUCTION}

$\mathrm{D}$ ata from the last national census show that widowed individuals account for nearly 9\% (3.1 million) of Polish population (Główny Urząd Statystyczny, 2013). Women dominate in this group in each age category (2.6 million). It is estimated that almost $50 \%$ of women over 70 years of age are widows (Szukalski, 2016). Considering the scale of the phenomenon, it seems important to address the issue of coping with grief among women. Death of a spouse is one of the most painful losses experienced by people during their lifetime. It also ranks at the top of the list of stressful life events by Holmes and Rahe (1967). According to Kersting et al. (2011), one in five widowed persons experience complicated grief. It may also be accompanied by other mental health disorders (Simon et al., 2007). Also, there is an increased risk of death for a widowed person soon after the death of their spouse. This global phenomenon is known as the widowhood effect (Moon et al., 2011).

Stroebe and Schut $(2010,1999)$ pointed to two categories of stressors associated with the death of a spouse. The first category are loss-oriented stressors, which are mainly associated with the irreversible separation from the loved one. The second category are restoration-oriented stressors, which are associated with the necessity to face new reality. The death of a spouse may entail many consequences and further losses, such as changes in daily duties as well as financial, social (limited contacts with mutual friends), and spiritual loss (the sense of losing one's own life path) (Steuden and Kurtyka-Chałas, 2009).

Stress triggers a remedial system. Coping with the death of a spouse is defined as "processes, strategies, or styles of managing [...] the situation in which bereavement places the individual" (as cited in Stroebe and Schut, 2010, p. 274). Stroebe and Schut (2010) have distinguished two coping processes for two stressor categories: loss-oriented coping and restoration-oriented coping. Loss-oriented coping aims to reorganise the internal model of the relationship with the deceased spouse (Bowlby, 1980; Stroebe et al., 2010). This process involves recalling memories of the deceased as well as cognitive and emotional processing of the painful event of death. In turn, restoration-oriented coping is aimed at adapting to the new reality, associated with making different life decisions or learning new things.

Oscillation between the above described coping processes is the key concept in the model proposed by Stroebe and Schut (2010). Therefore, individuals experiencing the death of a spouse are at one point faced with loss-related stressors, but they also avoid these stressors at another point to focus on the requirements of the new reality (Bielecka, 2012; Heszen, 2013). Oscillation between loss-oriented and restoration-oriented coping is necessary to adapt to the death of a spouse. The initially dominant loss-oriented coping is gradually replaced by restoration-oriented coping (Burton et al., 2006; Ludwikowska and Steuden, 2017).

\section{WSTĘP}

$\mathrm{D}$ ane pochodzące $\mathrm{z}$ ostatniego narodowego spisu powszechnego wskazują, że blisko 9\% (3,1 miliona) polskiej populacji stanowią osoby owdowiałe (Główny Urząd Statystyczny, 2013). W każdej kategorii wiekowej w grupie tej przeważają kobiety (2,6 miliona). Szacuje się, że prawie połowa kobiet, które ukończyły 70. rok życia, doświadczyła już śmierci współmałżonka (Szukalski, 2016). Biorąc pod uwagę skalę zjawiska, podjęcie tematu radzenia sobie z żałobą przez kobiety wydaje się istotne.

Śmierć współmałżonka jest jedną z najbardziej bolesnych utrat, jakich doświadczają ludzie w ciągu swojego życia. Na liście stresujących wydarzeń życiowych autorstwa Holmesa i Rahe’a (1967) znalazła się na pierwszym miejscu. Jak podają Kersting i wsp. (2011), wśród wdów i wdowców co piąta osoba doświadcza żałoby powikłanej. Towarzyszyć jej mogą także inne zaburzenia zdrowia psychicznego (Simon et al., 2007). Wykazano również zwiększone ryzyko śmiertelności osób owdowiałych w niedługim okresie od utraty współmałżonka. Zjawisko to, występujące na całym świecie, zostało nazwane efektem wdowieństwa (widowhood effect) (Moon et al., 2011). Stroebe i Schut $(2010,1999)$ zwracają uwagę na dwie kategorie stresorów działających na jednostkę w sytuacji śmierci współmałżonka. Do pierwszej kategorii należą stresory związane z utratą, których istotę stanowi nieodwracalna separacja od ukochanej osoby. Druga kategoria obejmuje stresory związane ze zmianą/odbudową - odnoszą się one do konieczności konfrontacji z nową rzeczywistością. Śmierć współmałżonka może bowiem pociągać za sobą szereg konsekwencji i dodatkowych strat: zmiany w zakresie codziennych obowiązków, straty ekonomiczne (finansowe), społeczne (zawężenie kontaktów ze wspólnymi znajomymi i przyjaciółmi) oraz duchowe (poczucie zagubienia własnej życiowej drogi) (Steuden i Kurtyka-Chałas, 2009).

Wskutek doświadczenia stresu uruchamia się system zaradczy. Radzenie sobie ze śmiercią współmałżonka określa się jako „zespół procesów, strategii bądź stylów (...) konfrontowania się z sytuacją utraty i związanymi z nią konsekwencjami" (za: Stroebe i Schut, 2010, s. 274). Stroebe i Schut (2010) wyróżniają dwa procesy radzenia sobie, adekwatnie do dwóch kategorii stresorów: proces radzenia sobie ukierunkowany na utratę (loss-oriented coping) i proces radzenia sobie ukierunkowany na zmianę/odbudowę (restorationoriented coping). Radzenie sobie zorientowane na utratę ma na celu reorganizację wewnętrznego modelu, w którym reprezentowana jest więź ze zmarłym współmałżonkiem (Bowlby, 1980; Stroebe et al., 2010). Proces ten wiąże się z przywoływaniem wspomnień dotyczących zmarłego oraz poznawczym i emocjonalnym przetwarzaniem bolesnego wydarzenia śmierci. Celem radzenia sobie zorientowanego na zmianę/odbudowę jest $\mathrm{z}$ kolei przystosowanie się do nowej rzeczywistości, związane z dokonywaniem różnorodnych zmian życiowych czy uczeniem się nowych rzeczy. Kluczowym pojęciem w modelu Stroebe i Schuta (2010) jest oscylacja między opisanymi wyżej procesami radzenia sobie. 
Disturbed oscillation makes the adaptation difficult and leads to complicated grief. Experiencing specific, intense emotions accompanied by significant deterioration of everyday functioning is the essence of complicated grief (Ludwikowska-Świeboda and Lachowska, 2019; Shear, 2015). This refers to such symptoms as strong longing for the deceased, difficulty accepting their death, anger and bitterness, difficulties trusting other people (since the loss), shock and astonishment, emotional numbness, a sense of emptiness or the lack of meaning in life (Prigerson and Jacobs, 2001; Prigerson et al., 2009). These symptoms may be common in the initial period of grief (acute grief), and they are not considered a disturbed response to spouse's death. The time elapsed since the loss of a spouse is an important criterion to differentiate between uncomplicated and complicated grief. According to the DSM-5 classification (American Psychiatric Association, 2013), this time is at least one year. However, periodic deterioration of functioning of a widowed person seen in anniversary reaction should be also considered (Tucholska, 2009).

Oscillation between loss- and restoration-oriented coping as well as the outcome of the entire process are determined by, among other things, intrapsychic factors, global attachment style in particular (Stroebe et al., 2010). The aim of this study was to verify its role in adapting to the death of a spouse among widowed women. The severity of complicated grief was used as the adaptation indicator.

Attachment style may be described using avoidance and anxiety dimensions (Fraley et al., 2000). High level of attachment avoidance translates into deactivation of the attachment system in a situation of danger. This is associated with negating the need for closeness, minimising the importance of close relationships, and relying only on one's own resources (Fraley and Bonanno, 2004). Individuals characterised by high levels of attachment avoidance are likely to avoid confrontation with loss-related stressors and intensely focus on life changes (Stroebe et al., 2010). However, some researchers point out that since these individuals are less likely to form strong emotional ties with loved ones, the experience of loss affects their sense of security to a lesser extent (Fraley and Bonanno, 2004). At the same time, difficulties in obtaining social support and establishing new relationships contribute to isolation after spouse's death, which may promote even greater dependence on the deceased and, in the long run, idealisation of the lost relationship (Maccallum and Bryant, 2018). Individuals characterised by high levels of attachment avoidance may therefore be at a higher risk of complicated grief. It was therefore assumed that attachment avoidance is an important predictor of complicated grief, and that this is a positive correlation (H1).

Attachment anxiety refers to a tendency to hyperactivate the attachment system in a situation of danger. Individuals characterised by high anxiety levels have a strong need for closeness and are motivated to seek this closeness (Miku-
A zatem osoby doświadczające śmierci współmałżonka czasem konfrontują się ze stresorami odnoszącymi się do utraty, a w innym momencie owych stresorów unikają i koncentrują się na wymaganiach nowej rzeczywistości (Bielecka, 2012; Heszen, 2013). Oscylacja między radzeniem sobie zorientowanym na utratę i zmianę jest konieczna do przystosowania się do sytuacji śmierci współmałżonka. Na początku żałoby dominuje orientacja na utratę, później stopniowo wzrasta udział orientacji na zmianę/odbudowę (Burton et al., 2006; Ludwikowska i Steuden, 2017).

Zaburzenia w zakresie oscylacji utrudniają przystosowanie się do śmierci współmałżonka i prowadzą do powikłań w procesie żałoby. Istotą żałoby powikłanej jest doświadczanie specyficznych intensywnych przeżyć, którym towarzyszy znaczne pogorszenie codziennego funkcjonowania (Ludwikowska-Ŝwieboda i Lachowska, 2019; Shear, 2015). Mowa tu o takich symptomach, jak silna tęsknota za zmarłym, trudności z zaakceptowaniem jego śmierci, gniew i rozgoryczenie, trudności w zaufaniu innym osobom (od momentu utraty), szok i zaskoczenie, emocjonalne odrętwienie, poczucie pustki czy braku sensu życia (Prigerson i Jacobs, 2001; Prigerson et al., 2009). W początkowym okresie żałoby (acute grief) powyższe symptomy mogą być powszechne i nie stanowią zaburzonej reakcji na śmierć współmałżonka. Ważnym kryterium, które pomaga odróżnić żałobę niepowikłaną od powikłanej, jest czas, który upłynął od utraty współmałżonka. W klasyfikacji DSM-5 wynosi on co najmniej rok (American Psychiatric Association, 2013). Należy jednak wziąć pod uwagę także okresowe pogorszenie funkcjonowania osoby owdowiałej związane z reakcją rocznicową (Tucholska, 2009).

Oscylacja między radzeniem sobie zorientowanym na utratę i zmianę oraz rezultaty całego procesu są uwarunkowane m.in. czynnikami intrapsychicznymi, wśród których szczególne miejsce zajmuje globalny styl przywiązania (Stroebe et al., 2010). Celem prezentowanych badań była weryfikacja jego roli w adaptacji do śmierci współmałżonka przez owdowiałe kobiety. Wskaźnik przystosowania stanowiło nasilenie żałoby powikłanej.

Styl przywiązania można opisać, posługując się wymiarami unikania i niepokoju (Fraley et al., 2000). Wysoki poziom unikania w przywiązaniu przekłada się na dezaktywację systemu przywiązania w sytuacji zagrożenia. Wiąże się to $\mathrm{z}$ negowaniem potrzeby bliskości, minimalizowaniem znaczenia bliskich relacji i poleganiem jedynie na własnych zasobach (Fraley i Bonanno, 2004). Osoby charakteryzujące się wysokim poziomem unikania w przywiązaniu mogą unikać konfrontowania się ze stresorami związanymi z utratą, czemu towarzyszy uporczywa koncentracja na zmianach życiowych (Stroebe et al., 2010). Niektórzy badacze zwracają jednak uwagę, że osoby te po prostu rzadziej tworzą silne emocjonalne więzi z bliskimi, dlatego doświadczenie straty w mniejszym stopniu narusza ich poczucie bezpieczeństwa (Fraley i Bonanno, 2004). Równocześnie trudności w uzyskaniu wsparcia społecznego i nawiązaniu nowych relacji pogłębiają izolację po śmierci współmałżonka, 


\begin{tabular}{|c|c|c|c|}
\hline $\begin{array}{l}\text { Demographic } \\
\text { variables } \\
\text { Zmienne } \\
\text { demograficzne }\end{array}$ & & $n$ & $\%$ \\
\hline \multirow{3}{*}{$\begin{array}{l}\text { Education } \\
\text { Wykształcenie }\end{array}$} & $\begin{array}{l}\text { Primary or basic vocational } \\
\text { Podstawowe lub zasadnicze } \\
\text { zawodowe }\end{array}$ & 23 & 38.3 \\
\hline & $\begin{array}{l}\text { Secondary or post-secondary } \\
\text { Średnie lub pomaturalne }\end{array}$ & 22 & 36.7 \\
\hline & $\begin{array}{l}\text { Higher or post-graduate } \\
\text { Wyższe lub podyplomowe }\end{array}$ & 15 & 25 \\
\hline \multirow{4}{*}{$\begin{array}{l}\text { Employment status } \\
\text { Sytuacja zawodowa }\end{array}$} & $\begin{array}{l}\text { Professional work } \\
\text { Praca zawodowa }\end{array}$ & 27 & 45.0 \\
\hline & $\begin{array}{l}\text { Pension/retirement pension } \\
\text { Renta/emerytura }\end{array}$ & 26 & 43.3 \\
\hline & $\begin{array}{l}\text { Unemployed } \\
\text { Osoba bezrobotna }\end{array}$ & 6 & 10.0 \\
\hline & $\begin{array}{l}\text { Other } \\
\text { Inna sytuacja }\end{array}$ & 1 & 1.7 \\
\hline \multirow{4}{*}{$\begin{array}{l}\text { Place of residence } \\
\text { Miejsce } \\
\text { zamieszkania }\end{array}$} & $\begin{array}{l}\text { Rural area } \\
\text { Wieś } \\
\end{array}$ & 31 & 51.7 \\
\hline & $\begin{array}{l}\text { Small-sized town } \\
(<50,000 \text { inhabitants) } \\
\text { Małe miasto ( }<50 \text { tys. mieszkańców) }\end{array}$ & 13 & 21.7 \\
\hline & $\begin{array}{l}\text { Medium-sized town } \\
\text { (50-150,000 inhabitants) } \\
\text { Średnie miasto } \\
\text { (50-150 tys. mieszkańców) }\end{array}$ & 10 & 16.7 \\
\hline & $\begin{array}{l}\text { Large city (>150,000 inhabitants) } \\
\text { Duże miasto (>150 tys. mieszkańców) }\end{array}$ & 6 & 10.0 \\
\hline
\end{tabular}

Tab. 1. Education, employment status and place of residence of the respondents

Tab. 1. Wykształcenie, sytuacja zawodowa i miejsce zamieszkania osób badanych

to Stroebe et al. (2010), they excessively focus on loss-related stressors and have a limited tendency to confront restoration-related stressors. Hyperactivation of the attachment system blocks competence motivation, which in turn makes it difficult to formulate new life goals and to cope after spouse's death (even a long time after spouse's death). As a result, the person becomes more prone to complicated grief (Mikulincer and Shaver, 2007; Shear and Shair, 2005). Therefore, attachment anxiety is an important predictor of complicated grief, and this is a positive correlation (H2).

\section{MATERIALS AND METHODS}

A questionnaire study was conducted among 60 widowed women to verify the above hypotheses. The research was conducted mainly in the Lubelskie and Świętokrzyskie provinces (nonrandom snowball sampling). All participants gave their informed written consent to participate in the study. The respondents were aged between 35 and 78 years $(M=59.69$; standard deviation, $S D=10.57)$, and their marriage duration was $3-50$ years $(M=28.95 ; S D=11.51)$. Theminimum and maximum time elapsed since spouse's death was 1 year and 2 months and 9 years, respectively $(M=4.52 ; S D=2.56)$. Other demographic data are presented in Tab. 1. co w dłuższej perspektywie może sprzyjać większej zależności od zmarłego oraz idealizowaniu utraconej relacji (Maccallum i Bryant, 2018). Osoby owdowiałe cechujące się wysokim poziomem unikania w przywiązaniu mogą być więc bardziej podatne na rozwój żałoby powikłanej. Założono zatem, że unikanie w przywiązaniu jest istotnym predyktorem żałoby powikłanej i że związek ten ma charakter dodatni (H1).

Niepokój w przywiązaniu oznacza tendencję do hiperaktywacji systemu przywiązania w sytuacji zagrożenia. Osoby charakteryzujące się wysokim poziomem niepokoju mają silną potrzebę bliskości i motywację do jej poszukiwania (Mikulincer i Shaver, 2007; Shear i Shair, 2005). Zdaniem Stroebe i wsp. (2010) nadmiernie koncentrują się na stresorach związanych $\mathrm{z}$ utratą i mają ograniczoną tendencję do konfrontowania się ze stresorami odnoszącymi się do zmiany/odbudowy. Hiperaktywacja systemu przywiązania blokuje motywację kompetencyjną, co z kolei utrudnia formułowanie nowych celów życiowych i radzenie sobie bez zmarłego (nawet po dłuższym czasie od jego śmierci). W rezultacie osoby te stają się bardziej podatne na rozwój żałoby powikłanej (Mikulincer i Shaver, 2007; Shear i Shair, 2005). Niepokój w przywiązaniu jest więc istotnym predyktorem żałoby powikłanej, a związek ten ma charakter dodatni (H2).

\section{MATERIA I METODA}

W celu weryfikacji postawionych hipotez przeprowadzono badania kwestionariuszowe wśród 60 kobiet, które doświadczyły śmierci współmałżonka. Badania odbywały się głównie w województwach lubelskim i świętokrzyskim (dobór nielosowy o charakterze kuli śniegowej). Wszystkie uczestniczki wyraziły świadomą pisemną zgodę na udział. Osoby badane były w wieku 35-78 lat $(M=59,69$; odchylenie standardowe, standard deviation, $S D=10,57)$, a ich staż małżeński wynosił 3-50 lat $(M=28,95 ; S D=11,51)$. Czas, jaki upłynął od momentu śmierci współmałżonka, to minimalnie rok i dwa miesiące, a maksymalnie - dziewięć lat $(M=4,52 ; S D=2,56)$. Pozostałe dane demograficzne zaprezentowano w tab. 1.

Do pomiaru żałoby powikłanej wykorzystano Inwentarz Żałoby Powikłanej (Inventory of Complicated Grief, ICG) Prigerson i wsp. (1995) w polskiej adaptacji Ludwikowskiej-Świebody i Lachowskiej (2019). Obejmuje on 19 stwierdzeń, które opisują odczucia i myśli związane ze śmiercią małżonka (przykładowa pozycja: „Tak dużo myślę o zmarłym współmałżonku, że trudno mi robić rzeczy, które zazwyczaj robię"). Osoby badane zaznaczają na pięciostopniowej skali (0 - nigdy, 4 - zawsze), jak często doświadczają określonych przeżyć. Im wyższy wynik, tym większe nasilenie żałoby powikłanej (Ludwikowska-Świeboda i Lachowska, 2019; Prigerson et al., 1995). Zgodnie z propozycją Simon i wsp. (2011) można przyjąć, że dany objaw występuje w stopniu klinicznym, gdy osoba badana zaznacza przy konkretnym stwierdzeniu odpowiedź „często” 
A Polish adaptation (Ludwikowska-Świeboda and Lachowska, 2019) of the Inventory of Complicated Grief (ICG) by Prigerson et al. (1995) was used for the measurement of complicated grief. It includes 19 statements describing feelings and thoughts associated with spouse's death (e.g. "I think about this person so much that it's hard for me to do the things I normally do"). Respondents use a 5-point scale ( 0 - never, 4 - always) to indicate how often they experience certain emotions. The higher the score, the higher the severity of complicated grief (Ludwikowska-Świeboda and Lachowska, 2019; Prigerson et al., 1995). As suggested by Simon et al. (2011), it may be assumed that a given symptom occurs at a clinical level when the respondent indicates "often" or "always" for a given statement. The statements may be also classified into six categories: yearning/preoccupation; anger/bitterness; disbelief/shock; behavioural change; estrangement from others; and hallucinations of the deceased (Simon et al., 2011).

Global attachment style was assessed using a Polish adaptation by Lubiewska et al. (2016) of the Experience in Close Relationships-Revised (ECR-R) by Fraley et al. (2000). The tool includes 36 questions, half of which refer to attachment anxiety, and half of which refer to the avoidance dimension. Respondents use a 7-point scale (1 - strongly disagree, 7 - strongly agree). The higher the score in a given subscale, the higher the level of anxiety or avoidance in attachment.

Both scales used have proven accuracy and reliability.

\section{RESULTS}

Since the group of respondents varied in terms of the time elapsed from spouse's death, this variable was controlled and considered in the analyses. In the first stage of the analysis, relationships between variables were identified. The results of analyses are presented in Tab. 2 .

The main stage of analyses involved verification of hypotheses, including the covariance of the postulated predictors of complicated grief. Although the dimension of avoidance in attachment showed no relationship with complicated grief, it was included in further analyses (Tab. 3) due to the possible suppression effect.

\begin{tabular}{|c|c|c|c|c|c|}
\hline & $M$ & SD & 1 & 2 & 3 \\
\hline $\begin{array}{l}\text { 1. Complicated grief } \\
\text { 1. Żałoba powikłana }\end{array}$ & 34.97 & 16.02 & & & \\
\hline $\begin{array}{l}\text { 2. Anxiety } \\
\text { 2. Niepokój }\end{array}$ & 58.47 & 21.08 & $0.29^{*}$ & & \\
\hline $\begin{array}{l}\text { 3. Avoidance } \\
\text { 3. Unikanie }\end{array}$ & 59.13 & 13.76 & 0.03 & $0.38^{* *}$ & \\
\hline $\begin{array}{l}\text { 4. Time elapsed since } \\
\text { spouse's death } \\
\text { 4. Okres, jaki upłynał od } \\
\text { śmierci współmałżonka }\end{array}$ & 4.52 & 2.56 & $-0.29 *$ & -0.04 & -0.11 \\
\hline
\end{tabular}

Tab. 2. Pearson r-correlation coefficients between variables

Tab. 2. Współczynniki korelacji $\mathrm{r}$-Pearsona między zmiennymi lub „zawsze”. Możliwe jest także pogrupowanie stwierdzeń w sześć kategorii: zaabsorbowanie osobą zmarłą i tęsknota za nią, rozgoryczenie i złość, szok i niedowierzanie, zmiany w zachowaniu, izolowanie się od innych ludzi, halucynacje związane ze zmarłym (Simon et al., 2011).

Do badania globalnego stylu przywiązania posłużyła Zrewidowana Skala Doświadczeń w Bliskich Relacjach (Experience in Close Relationships, ECR-R) autorstwa Fraleya i wsp. (2000) w polskiej adaptacji Lubiewskiej i wsp. (2016). Skala składa się z 36 pytań, z których połowa odnosi się do niepokoju w przywiązaniu, a druga połowa - do wymiaru unikania. Osoba badana zaznacza odpowiedzi na skali siedmiostopniowej ( 1 - zdecydowanie się nie zgadzam, 7 - zdecydowanie się zgadzam). Im wyższy wynik w danej podskali, tym większe nasilenie niepokoju albo unikania w przywiązaniu.

Obie wykorzystane skale mają potwierdzoną trafność i rzetelność.

\section{WYNIKI}

Ponieważ grupa uczestniczek była zróżnicowana ze względu na okres, jaki upłynął od śmierci współmałżonka, zmienną tę kontrolowano i brano pod uwagę w analizach. W pierwszym etapie identyfikowano związki między zmiennymi. Rezultaty analiz wstępnych zaprezentowano w tab. 2.

Właściwy etap analiz obejmował weryfikację hipotez z uwzględnieniem współzmienności postulowanych predyktorów żałoby powikłanej. Wymiar unikania w przywiązaniu nie wykazywał związku z żałobą powikłaną, jednak ze względu na możliwy efekt supresji został włączony do dalszych analiz, których wyniki przedstawiono w tab. 3 .

Istotnymi predyktorami żałoby powikłanej są niepokój w przywiązaniu i okres, jaki upłynął od śmierci współmałżonka. Im wyższy niepokój w przywiązaniu $(\beta=0,32$; $p<0,05)$ i im krótszy czas od utraty $(\beta=-0,29 ; p<0,05)$, tym większe nasilenie żałoby powikłanej. Związek między unikaniem w przywiązaniu a żałobą powikłaną nie jest istotny statystycznie (por. tab. 3). Przedstawiony model wyjaśnia nasilenie żałoby powikłanej w 13\% (skorygowane $\left.R^{2}\right)$ i jest dobrze dopasowany do danych $[F(3,56)=3,86$; $p<0,05]$.

\begin{tabular}{|l|c|c|c|c|c|}
\hline $\begin{array}{l}\text { Predictor } \\
\text { Predyktor }\end{array}$ & $\boldsymbol{b}$ & SE & $\boldsymbol{\beta}$ & $\boldsymbol{t}$ & $\boldsymbol{p}$ \\
\hline $\begin{array}{l}\text { Anxiety } \\
\text { Niepokój }\end{array}$ & $\mathbf{0 . 2 5}$ & $\mathbf{0 . 1 0}$ & $\mathbf{0 . 3 2}$ & $\mathbf{2 . 4 5}$ & $\mathbf{0 . 0 2}$ \\
\hline $\begin{array}{l}\text { Avoidance } \\
\text { Unikanie }\end{array}$ & -0.14 & 0.15 & -0.12 & -0.92 & 0.36 \\
\hline $\begin{array}{l}\text { Time elapsed since } \\
\text { spouse's death } \\
\text { Okres, jaki upłynał od } \\
\text { śmierci współmałżonka }\end{array}$ & $\mathbf{- 1 . 8 0}$ & $\mathbf{0 . 7 7}$ & $\mathbf{- 0 . 2 9}$ & $\mathbf{- 2 . 3 5}$ & $\mathbf{0 . 0 2}$ \\
\hline
\end{tabular}

Tab. 3. Results of multivariate regression analysis for complicated grief

Tab. 3. Wyniki analizy regresji wielozmiennowej dla żałoby powikłanej 


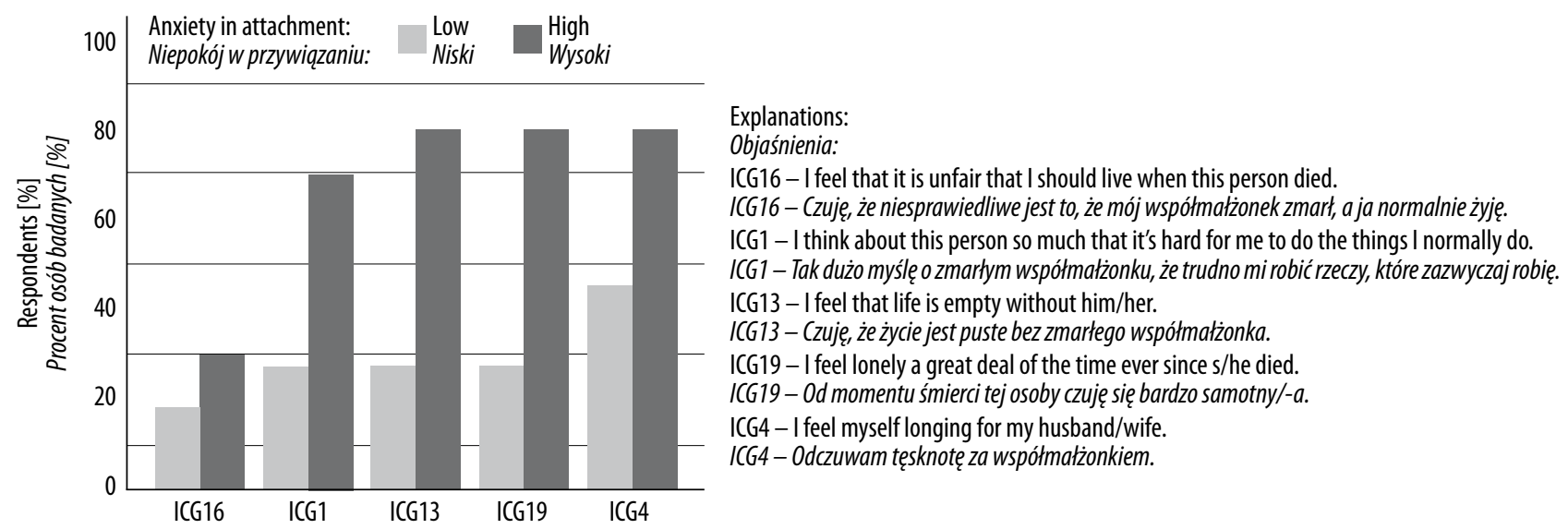

Fig. 1. The percentage of respondents experiencing symptoms in the category of "yearning/preoccupation" at a clinical level (with classification into low and high anxiety groups)

Ryc. 1. Odsetek osób doświadczających objawów z kategorii „zaabsorbowanie osobą zmarłą i tęsknota za nią" w stopniu klinicznym (w podziale na grupy z niskim i wysokim poziomem niepokoju)

Attachment anxiety and the time elapsed since spouse's death were important predictors of complicated grief. The higher the level of attachment anxiety $(\beta=0.32$; $p<0.05)$ and the shorter the time elapsed since the loss $(\beta=-0.29 ; p<0.05)$, the higher the severity of complicated grief. The relationship between attachment avoidance and complicated grief was not statistically significant (cf. Tab. 3). The presented model explains $13 \%$ of the severity of complicated grief (adjusted $R^{2}$ ) and is well matched to the data $[F(3,56)=3.86 ; p<0.05]$.

Additional analyses were performed to find out which of the symptoms of complicated grief differentiated individuals with low and high levels of attachment anxiety. First, groups of respondents with low and high anxiety levels (low anxiety level - results below one standard deviation from the mean; high anxiety level - results above one standard deviation from the mean) were distinguished. Then, as in accordance with Simon et al. (2011), the number of
Aby ustalić, które z objawów żałoby powikłanej różnicują osoby charakteryzujące się niskim i wysokim poziomem niepokoju w przywiązaniu, przeprowadzono dodatkowe analizy. Na początku wyodrębniono grupę uczestniczek z niskim i wysokim poziomem niepokoju (niski poziom niepokoju - wyniki poniżej jednego odchylenia standardowego od średniej; wysoki poziom niepokoju - wyniki powyżej jednego odchylenia standardowego od średniej). Następnie, zgodnie z propozycją Simon i wsp. (2011), w każdej z grup ustalono liczbę osób, które doświadczają poszczególnych symptomów żałoby powikłanej w stopniu klinicznym. Istotność różnic między grupami oszacowano za pomocą testu chi-kwadrat Pearsona. Wyniki zaprezentowano $\mathrm{w}$ formie graficznej na rycinach, uwzględniając najważniejsze kategorie objawów żałoby powikłanej.

Osiemdziesiąt procent kobiet z grupy cechującej się wysokim poziomem niepokoju $\mathrm{w}$ dużym stopniu odczuwa tęsknotę za współmałżonkiem, pustkę i samotność.

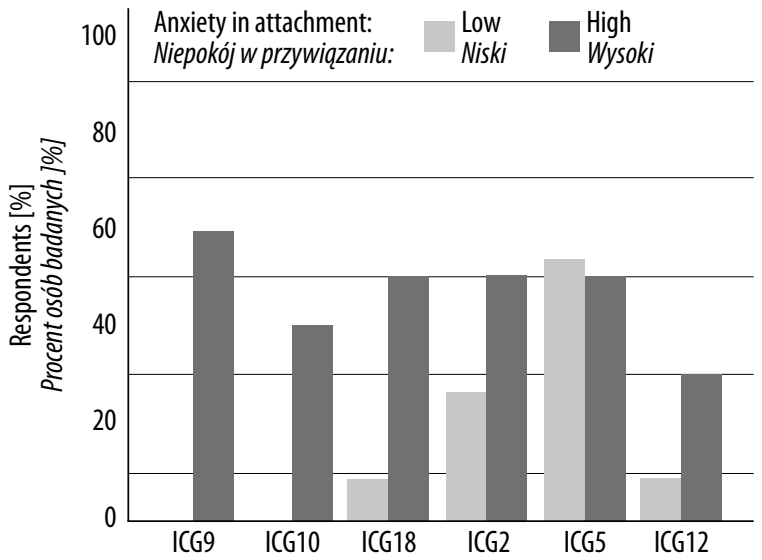
Explanations: Objaśnienia:
ICG9 - Ever since he/she died, it is hard for me to trust people. ICG9-Odkad on (ona) zmarł(a), trudno mi zaufać ludziom.
ICG10 - Ever since he/she died, I feel like I have lost the ability to care about other people or I feel distant from people I care about.
ICG10 - Od kiedy on (ona) zmarł(a), czuję się, jakbym stracił(a) zainteresowanie innymi ludźmi, lub odczuwam dystans wobec ludzi, na których mi zależy.
IG18 - I feel envious of others who have not lost someone close. ICG18 - Zazdroszczę innym ludziom, których bliscy nie zmarli.
ICG2 - Memories of him/her upset me.
ICG2 - Wspominanie zmarłego wspótmałżonka wytrąca mnie z równowagi.
ICG5 - I feel drawn to the places and things associated with him/her.
ICG5 - Czuje, że miejsca i rzeczy zwiqzane ze współmałżonkiem przyciagaja mnie.
ICG12 - I go out of my way to avoid reminders of my spouse.
ICG12 - Staram się unikać rzeczy, które przypominają mi współmałżonka.

Fig. 2. The percentage of respondents experiencing symptoms in the category of "estrangement from others" at a clinical level (with classification into low and high anxiety groups)

Ryc. 2. Odsetek osób doświadczających objawów z kategorii „izolowanie się od innych ludzi” oraz „zmiany w zachowaniu” w stopniu klinicznym (w podziale na grupy z niskim i wysokim poziomem niepokoju) 
respondents who experienced different clinical symptoms of complicated grief was determined for each group. The significance of differences between the groups was estimated using the Pearson chi-square test. The results are presented in graphic form in the figures, including the key categories of the symptoms of complicated grief.

The study showed that $80 \%$ of women in the group with high levels of attachment anxiety experienced strong yearning for the deceased husband, emptiness and loneliness. Also, $70 \%$ of respondents experienced preoccupation with the deceased. As for the group of women characterised by low levels of attachment anxiety, $45 \%$ experienced strong yearning for the deceased, while $27 \%$ experienced loneliness, emptiness and preoccupation with the deceased (cf. Fig. 1). The conducted analyses (Pearson's chi-square test) showed statistically significant differences between both groups in terms of loneliness $\left(\chi^{2}=5.84\right.$; $\left.p<0.05\right)$, emptiness $\left(\chi^{2}=5.84 ; p<0.05\right)$ and preoccupation with the deceased spouse $\left(\chi^{2}=3.84 ; p=0.05\right)$. These symptoms are experienced at a clinical level by more individuals with high anxiety levels than those with low anxiety levels.

In the group with high levels of attachment anxiety, $60 \%$ of women indicated significant difficulties in trusting other people since the death of their spouse, and $40 \%$ reported having distance to people. Half of women in this group envied those who have not experienced a similar loss, experienced discomfort on mentioning the deceased, or were preoccupied with things and places associated with this person. None of the respondents in the group with low anxiety levels indicated lack of trust or distance towards loved ones since the death of their spouses (cf. Fig. 2). Analyses showed statistically significant differences between the two groups in terms of difficulty trusting people $\left(\chi^{2}=9.24\right.$; $p<0.01)$, distance towards them $\left(\chi^{2}=5.44 ; p<0.05\right)$ and envy $\left(\chi^{2}=4.30 ; p<0.05\right)$. At a clinical level, the above symptoms were more common in women with high vs. low anxiety levels (Fig. 3).
Siedemdziesiąt procent osób doświadcza zaabsorbowania myśleniem o zmarłym. W grupie kobiet charakteryzujących się niskim poziomem niepokoju w przywiązaniu $45 \% \mathrm{w}$ dużym stopniu odczuwa tęsknotę za zmarłym, a 27\% - samotność i pustkę oraz zaabsorbowanie myśleniem o zmarłym (por. ryc. 1). Przeprowadzone analizy (chi-kwadrat Pearsona) ukazują istotne statystycznie różnice między obiema grupami w zakresie samotności $\left(\chi^{2}=5,84 ; p<0,05\right)$, pustki $\left(\chi^{2}=5,84 ; p<0,05\right)$ i zaabsorbowania myślami o współmałżonku $\left(\chi^{2}=3,84 ; p=0,05\right)$. Wymienionych objawów w stopniu klinicznym doświadcza więcej osób $\mathrm{z}$ wysokim poziomem niepokoju niż z niskim poziomem niepokoju.

$\mathrm{W}$ grupie charakteryzującej się wysokim poziomem niepokoju w przywiązaniu $60 \%$ kobiet wskazało na znaczące trudności w zaufaniu innym ludziom od momentu śmierci współmałżonka, a $40 \%$ - na dystans wobec nich. Połowa kobiet $\mathrm{z}$ tej grupy zazdrości osobom, które nie doświadczyły podobnej utraty, odczuwa dyskomfort w sytuacji wspominania współmałżonka bądź jest zaabsorbowana rzeczami i miejscami z nim związanymi. W grupie cechującej się niskim poziomem niepokoju żadna z uczestniczek nie wskazała na brak zaufania lub dystans wobec bliskich osób od momentu śmierci współmałżonka (por. ryc. 2). Analizy ukazują istotne statystycznie różnice między obiema grupami w zakresie trudności w zaufaniu ludziom $\left(\chi^{2}=9,24 ; p<0,01\right)$, dystansu wobec nich $\left(\chi^{2}=5,44 ; p<0,05\right)$ i zazdrości $\left(\chi^{2}=4,30 ; p<0,05\right)$. Powyższe objawy w stopniu klinicznym występują u większej liczby kobiet $\mathrm{z}$ wysokim poziomem niepokoju niż z niskim poziomem niepokoju (ryc. 3). Dla $80 \%$ kobiet $\mathrm{z}$ wysokim poziomem niepokoju w przywiązaniu śmierć współmałżonka nadal łączy się z niedowierzaniem, a 50\% osób z tej grupy ma trudności z zaakceptowaniem utraty. Również $50 \%$ odczuwa rozgoryczenie, $40 \%$ - złość. W grupie charakteryzującej się niskim poziomem niepokoju $27 \%$ uczestniczek wskazuje na niedowierzanie, a niecała połowa - na trudności z zaakceptowaniem śmierci współmałżonka. Analizy ukazują istotne

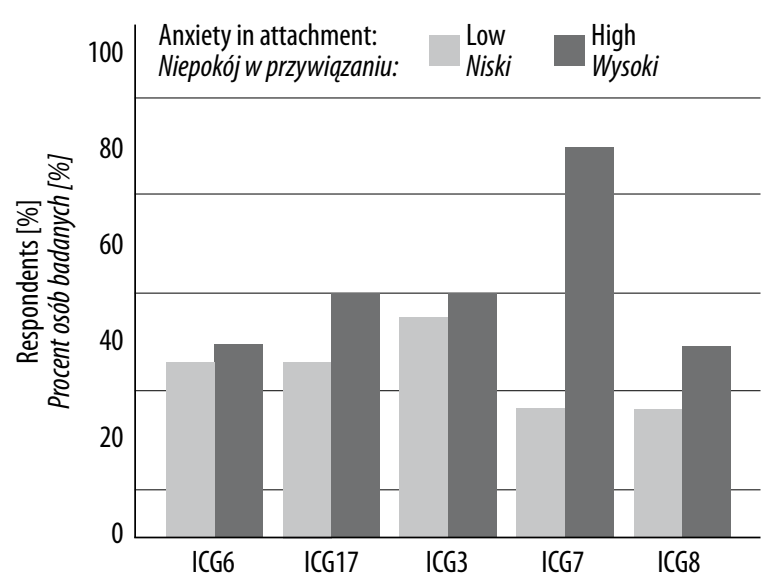
Explanations:
Objaśnienia:

ICG6 - I can't help feeling angry about his/her death.

IGG6 - Nie mogę powstrzymać się od odczuwania złości w zwiq̨zku ze śmierciq współmałżonka. ICG17 - I feel bitter over his/her death.

ICG17 - Czuję się rozgoryczony(a) jej (jego) śmiercią.

ICG3 - I feel I cannot accept the death of my husband/wife.

ICG3 - Czuję, że nie mogę zaakceptować tego, że on (ona) nie żyje.

ICG7 - I feel disbelief over what happened.

ICG7-Nie mogę uwierzyć w to, co się stało.

ICG8 - I feel stunned or dazed over what happened.

ICG8 - Czuję sięzzzokowany(a) lub oszołomiony(a) tym, co się stało.

Fig. 3. The percentage of respondents experiencing symptoms in the category of "bitterness and anger" at a clinical level (with classifcation into low and high anxiety groups)

Ryc. 3. Odsetek osób doświadczających objawów z kategorii „rozgoryczenie i złość” oraz „szok i niedowierzanie” w stopniu klinicznym (w podziale na grupy z niskim i wysokim poziomem niepokoju)) 
A total of $80 \%$ of women with high levels of attachment anxiety reported disbelief in their spouse's death, and 50\% of women in this group had difficulty accepting the loss. Bitterness and anger were reported by $50 \%$ and $40 \%$ of women, respectively. Disbelief was reported by $27 \%$ of respondents in the group with low anxiety levels, while difficulty accepting spouse's death was reported by nearly half of participants. Statistically significant differences were found between the groups for disbelief $\left(\chi^{2}=5.84 ; p<0.05\right)$, which was more common among respondents with high vs. low anxiety levels.

\section{DISCUSSION}

The study did not confirm the positive relationship between attachment avoidance and complicated grief (H1). However, as expected, anxiety in attachment was found to be a significant predictor of complicated grief (H2). Women characterised by high levels of anxiety showed greater preoccupation with the deceased spouse, disbelief in his death despite the passage of time as well as the feeling of emptiness and loneliness. They were more likely to face difficulty trusting other people and distance themselves from the loved ones. The severity of complicated grief also depends on the time elapsed from the death of a spouse.

Previous studies on the relationship between attachment avoidance and the severity of complicated grief were contradictory. Some studies point to the negative or statistically insignificant relationship between the above variables (Fraley and Bonanno, 2004; Wayment and Vierthaler, 2002), whereas other studies indicate a positive correlation (Boelen and Klugkist, 2011). The relationship in question may be determined by a number of moderating variables, such as death circumstances or the quality of the relationship with the deceased. Research has shown that high levels of avoidance promote complicated grief, but only in the case of negative assessment of the relationship with the deceased spouse (Mancini et al., 2009) and/or traumatic circumstances of his/her death (Meier et al., 2013). These factors cause that coping strategies related to the suppression of negative experiences, which are usually used by individuals with high levels of avoidance, break down, leading to increased psychopathological symptoms. A positive relationship with the deceased and natural death circumstances allow for effective adaptation to the new situation (Fraley and Bonanno, 2004).

The positive correlation between attachment anxiety and the severity of complicated grief was also confirmed by other authors (Fraley and Bonanno, 2004; Mancini et al., 2009; Wayment and Vierthaler, 2002). Individuals characterised by high levels of attachment anxiety are therefore at an increased risk of complicated grief. Despite the passage of time, they remain preoccupied with the deceased spouse and his/her death, which can escalate the lack of understanding among loved ones and intensify the feeling of loneliness. They may also experience emptiness and difficulties statystycznie różnice między obiema grupami w zakresie niedowierzania $\left(\chi^{2}=5,84 ; p<0,05\right)$, które dotyczy większej liczby osób z wysokim niż z niskim poziomem niepokoju.

\section{OMÓWIENIE}

Wyniki przeprowadzonych badań nie potwierdziły dodatniego związku między unikaniem w przywiązaniu a żałobą powikłaną (H1). Natomiast zgodnie z przewidywaniami istotnym predyktorem żałoby powikłanej okazał się niepokój w przywiązaniu (H2). Kobiety charakteryzujące się wysokim poziomem niepokoju są w większym stopniu zaabsorbowane myśleniem o współmałżonku, mimo upływu czasu nie dowierzają, że on zmarł, odczuwają pustkę i samotność. Częściej doświadczają trudności w zaufaniu innym ludziom i dystansu wobec bliskich. Znaczenie dla nasilenia żałoby powikłanej ma także okres, jaki upłynął od śmierci małżonka.

Dotychczasowe badania relacji między unikaniem w przywiązaniu a nasileniem żałoby powikłanej przyniosły sprzeczne rezultaty. Niektóre prace wskazują na ujemny albo nieistotny statystycznie związek między powyższymi zmiennymi (Fraley i Bonanno, 2004; Wayment i Vierthaler, 2002), podczas gdy inne - na związek dodatni (Boelen i Klugkist, 2011). Omawiana zależność może być więc uwarunkowana szeregiem zmiennych moderujących, do których należą okoliczności śmierci bliskiej osoby czy jakość relacji ze zmarłym. Badania dowiodły, że wysoki poziom unikania w przywiązaniu sprzyja powikłaniom procesu żałoby, ale tylko w przypadku niskiej oceny relacji ze zmarłym współmałżonkiem (Mancini et al., 2009) i/lub traumatycznych okoliczności jego śmierci (Meier et al., 2013). Czynniki te sprawiają, że strategie radzenia sobie związane $\mathrm{z}$ supresją negatywnych przeżyć - zazwyczaj wykorzystywane przez osoby z wysokim poziomem unikania - załamują się, co zwiększa nasilenie różnych objawów psychopatologicznych. W przypadku dobrej relacji ze zmarłym i tak zwanych naturalnych okoliczności utraty osoby te mogą skutecznie przystosowywać się do nowej sytuacji (Fraley i Bonanno, 2004).

Dodatni związek między niepokojem w przywiązaniu a nasileniem żałoby powikłanej został potwierdzony także w innych badaniach (Fraley i Bonanno, 2004; Mancini et al., 2009; Wayment i Vierthaler, 2002). Osoby charakteryzujące się wysokim poziomem niepokoju w przywiązaniu są zatem w większym stopniu narażone na komplikacje w przebiegu procesu żałoby. Mimo upływu czasu pozostają zaabsorbowane zmarłym współmałżonkiem i jego śmiercią, co może budzić coraz większe niezrozumienie wśród bliskich i potęgować poczucie osamotnienia. Osoby te mogą również przejawiać trudności $\mathrm{w}$ radzeniu sobie $\mathrm{z}$ nowymi wyzwaniami, które są konsekwencją utraty współmałżonka, oraz doświadczać pustki. Opisaną tendencję pogłębiają bieżące zmiany i trudności: problemy finansowe, wycofanie się z życia zawodowego (przejście na emeryturę) czy zmiany cywilizacyjne (cyfrowe i inne), za którymi trudniej nadążyć ludziom starszym. 
in coping with new challenges faced after spouse's death. This tendency is intensified by changes and difficulties, such as financial problems, withdrawal from professional life (retirement) or civilisation changes (e.g. digital revolution), which are more difficult for older people to keep up with.

The negative relationship between time elapsed from the death of a spouse and the severity of complicated grief seems interesting. Considering the selection of the group in this study (the minimum period since the loss was 1.2 years), this relationship may suggest that some symptoms of complicated grief are not necessarily persistent. However, this is not a very significant effect - the entire model accounts for only $13 \%$ of the variance in complicated grief. Longitudinal studies in a clinical population are needed to confirm this hypothesis.

\section{CONCLUSIONS}

The study showed that high levels of attachment anxiety may promote complicated grief also among Polish women. Therefore, the supportive role of family and friends, who can create space for sharing feelings and experiences, is of key importance. It was pointed out that people with high levels of attachment anxiety may have difficulty confronting the requirements of a changed reality. Therefore, it is also important to help a widowed person discover resources for coping with new challenges and to support their sense of efficiency and resourcefulness.

\section{Conflict of interest}

The author does not report any financial or personal connections with other persons or organisations, which might negatively affect the contents of this publication and/or claim authorship rights to this publication.

\section{References / Piśmiennictwo}

American Psychiatric Association: Diagnostic and Statistical Manual of Mental Disorders (DSM-5 ${ }^{\circ}$ ). American Psychiatric Publishing, Washington, DC 2013.

Bielecka U: Mity na temat zdrowej i patologicznej żałoby. Psychiatr Psychol Klin 2012; 12: 62-66.

Boelen PA, Klugkist I: Cognitive behavioral variables mediate the associations of neuroticism and attachment insecurity with prolonged grief disorder severity. Anxiety Stress Coping 2011; 24: 291-307.

Bowlby J: Attachment and Loss: Vol. III: Loss - Sadness and Depression. Basic Books, New York 1980.

Burton AM, Haley WE, Small BJ: Bereavement after caregiving or unexpected death: effects of elderly spouses. Aging Ment Health 2006; 10: 319-326.

Fraley RC, Bonanno GA: Attachment and loss: a test of three competing models on the association between attachment-related avoidance and adaptation to bereavement. Pers Soc Psychol Bull 2004; 30: 878-890.

Fraley RC, Waller NG, Brennan KA: An item response theory analysis of self-report measures of adult attachment. J Pers Soc Psychol 2000; 78: 350-365.
Interesujący wydaje się ujemny związek między czasem, jaki upłynął od momentu śmierci współmałżonka, a nasileniem objawów żałoby powikłanej. Biorąc pod uwagę dobór grupy w prezentowanych badaniach (minimalny okres od utraty wynosił 1,2 roku), zależność ta może sugerować, że pewne objawy żałoby powikłanej nie muszą mieć charakteru trwałego i uporczywego. Nie jest to jednak efekt bardzo znaczący - cały model wyjaśnia zaledwie $13 \%$ wariancji żałoby powikłanej. Aby potwierdzić powyższą hipotezę, należałoby przeprowadzić badania podłużne w grupie klinicznej.

\section{WNIOSKI}

Dowiedziono, że wysoki poziom niepokoju w przywiązaniu może sprzyjać powikłaniom procesu żałoby także wśród kobiet pochodzących z polskiej populacji. Szczególnie istotna jest zatem wspierająca postawa otoczenia, która stwarza przestrzeń do dzielenia się własnymi uczuciami i przeżyciami. Zwrócono uwagę, że osoby charakteryzujące się wysokim poziomem niepokoju w przywiązaniu mogą mieć trudności z konfrontowaniem się z wymaganiami zmienionej rzeczywistości. Istotne jest więc również towarzyszenie osobie owdowiałej w odkrywaniu zasobów związanych z radzeniem sobie z nowymi wyzwaniami oraz wspieranie poczucia skuteczności i zaradności.

\section{Konflikt interesów}

Autorka nie zgłasza żadnych finansowych ani osobistych powiązań $z$ innymi osobami lub organizacjami, które mogtyby negatywnie wplynać na treść publikacji oraz rościć sobie prawo do tej publikacji.

Główny Urząd Statystyczny: Ludność. Stan i struktura demograficzno-społeczna. Narodowy Spis Powszechny Ludności i Mieszkań 2011. Główny Urząd Statystyczny, Warszawa 2013.

Heszen I: Psychologia stresu. Korzystne i niekorzystne skutki stresu życiowego. Wydawnictwo Naukowe PWN, Warszawa 2013.

Holmes TH, Rahe RH: The Social Readjustment Rating Scale. J Psychosom Res 1967; 11: 213-218.

Kersting A, Brähler E, Glaesmer H et al.: Prevalence of complicated grief in a representative population-based sample. J Affect Disord 2011; 131: 339-343.

Lubiewska K, Głogowska K, Mickiewicz K et al.: Skala Experience in Close Relationships-Revised: struktura, rzetelność oraz skrócona wersja skali w polskiej próbie. Psychologia Rozwojowa 2016; 21 : 49-63.

Ludwikowska K, Steuden S: Radzenie sobie ze stratą i sposób doświadczania śmierci rodzica przez osoby dorosłe pochodzące $\mathrm{z}$ rodzin alkoholowych i niealkoholowych. Polskie Forum Psychologiczne 2017; 22: 20-39.

Ludwikowska-Świeboda K, Lachowska B: Polska wersja Inwentarza Żałoby Powikłanej - wstępna walidacja. Psychiatr Pol 2019; 53: 1069-1086.

Maccallum F, Bryant RA: Prolonged grief and attachment security: a latent class analysis. Psychiatry Res 2018; 268: 297-302.

Mancini AD, Robinaugh D, Shear K et al.: Does attachment avoidance help people cope with loss? The moderating effects of relationship quality. J Clin Psychol 2009; 65: 1127-1136.

Meier AM, Carr DR, Currier JM et al.: Attachment anxiety and avoidance in coping with bereavement: two studies. J Soc Clin Psychol 2013; 32: 315-334. 


\section{Attachment style and experiencing the symptoms of complicated grief after the death of a spouse - preliminary research among widowed women \\ Styl przywiązania a doświadczanie objawów żałoby powikłanej po śmierci współmałżonka - badania wstępne wśród owdowiałych kobiet}

Mikulincer M, Shaver PR: Attachment in Adulthood: Structure, Dynamics, and Change. Guilford Press, New York 2007.

Moon JR, Kondo N, Glymour MM et al.: Widowhood and mortality: a meta-analysis. PloS One 2011; 6: e23465.

Prigerson HO, Jacobs SC: Traumatic grief as a distinct disorder: a rationale, consensus criteria, and a preliminary empirical test. In: Stroebe MS, Hansson RO, Stroebe W et al. (eds.): Handbook of Bereavement Research: Consequences, Coping, and Care. American Psychological Association, Washington, DC 2001: 613-645.

Prigerson HG, Horowitz MJ, Jacobs SC et al.: Prolonged grief disorder: psychometric validation of criteria proposed for DSM-V and ICD-11. PLoS Med 2009; 6: e1000121.

Prigerson HG, Maciejewski PK, Reynolds CF $3^{\text {rd }}$ et al.: Inventory of Complicated Grief: a scale to measure maladaptive symptoms of loss. Psychiatry Res 1995; 59: 65-79.

Shear K, Shair H: Attachment, loss, and complicated grief. Dev Psychobiol 2005; 47: 253-267.

Shear MK: Clinical practice. Complicated grief. N Engl J Med 2015; 372: 153-160.

Simon NM, Shear KM, Thompson EH et al.: The prevalence and correlates of psychiatric comorbidity in individuals with complicated grief. Compr Psychiatry 2007; 48: 395-399.
Simon NM, Wall MM, Keshaviah A et al.: Informing the symptom profile of complicated grief. Depress Anxiety 2011; 28: 118-126.

Steuden S, Kurtyka-Chałas J: Dynamika procesu przeżywania straty związanej ze śmiercią współmałżonka. In: Steuden S, Tucholska S (eds.): Psychologiczne aspekty doświadczania żałoby. Wydawnictwo KUL, Lublin 2009: 124-143.

Stroebe M, Schut H: The dual process model of coping with bereavement: a decade on. Omega (Westport) 2010; 61: 273-289.

Stroebe M, Schut H: The dual process model of coping with bereavement: rationale and description. Death Stud 1999; 23: 197-224.

Stroebe M, Schut H, Boerner K: Continuing bonds in adaptation to bereavement: toward theoretical integration. Clin Psychol Rev 2010; 30: 259-268.

Szukalski P: Owdowienia we współczesnej Polsce. Demografia i Gerontologia Społeczna - Biuletyn Informacyjny 2016; nr 9: 1-4.

Tucholska S: Psychologiczna analiza procesu żałoby. In: Steuden S, Tucholska S (eds.): Psychologiczne aspekty doświadczania żałoby. Wydawnictwo KUL, Lublin 2009: 12-33.

Wayment HA, Vierthaler J: Attachment style and bereavement reactions. J Loss Trauma 2002; 7: 129-149. 